\title{
An Investigation of Pre-Service Primary School Teachers' Attitudes towards Digital Technology and Digital Citizenship Levels in Terms of Some Variables
}

\author{
Serdar Çiftci ${ }^{1} \&$ Soner Aladağ ${ }^{1}$ \\ ${ }^{1}$ Faculty of Education, Adnan Menderes University, Aydın, Turkey \\ Correspondence: Serdar Çiftci, Egitim Fakultesi Adnan Menderes Universitesi, Efeler/Aydın, Turkey. E-mail: \\ serdar.ciftci@adu.edu.tr
}

Received: August 16, 2017

Accepted: November 20, 2017 Online Published: December 22, 2017

doi:10.5539/ies.v11n1p111

URL: https://doi.org/10.5539/ies.v11n1p111

\begin{abstract}
This study aims at investigating the relationship between pre-service primary school teachers' attitudes towards digital technology and digital citizenship scale levels. The research was designed in descriptive survey model. The data collection tools were "Attitude Scale for Digital Technology" (ASDT) developed by Cabı (2016) and "Digital Citizenship Scale" (DCS) developed by Isman and Gungoren (2014). Some of the research findings are as follows: While there is a statistically insignificant difference between pre-service teachers' scores from two scales in terms of the variable of gender, the variable of class creates a statistically significant difference between the scores from two scales. The scores from the Attitude Scale for Digital Technology was not affected by the number of years pre-service teachers had spent using the Internet, whereas the same variable affected their Digital Citizenship Scale scores. When the correlations were analyzed, it was seen the relationship between digital attitude and digital citizenship was positive and significant, i.e. as the digital attitude scores of the participants increase, so do their digital citizenship scores.
\end{abstract}

Keywords: attitude towards digital technology, digital citizenship, pre-service primary school teachers

\section{Introduction}

Advancement in technology creates new research fields. Technology is an indispensable part of our lives due to its extensive usage. The word technology in recent studies connotes digital technology. Today, technological devices can be mainly categorized as digital technology products.

Compass, telescope, battery, elevator, television, computer, operating system, and the Internet can be listed among many other technological inventions (Kalelioğlu, 2013). Various types of audio-visual, printed and written material which facilitate finding and creating information have created the concept of information and communications technology (ICT) (Coşkun, 2015). With the digitalization of telecommunication systems, digital data can be transmitted easily and quickly and the term of digital technology has been widespread under the category of ICT (Cab1, 2016).

Some popular platforms such as Facebook, Twitter, Youtube and smart devices along with the Internet are digital technology products. These products are expected to contribute positively. There are numerous studies which investigate the terms of technology along with the word "addiction." Some examples are mobile phone addiction and Internet addiction. In addition to that, new concepts such as cyber-bullying emerge as the acts of bullying are transferred to cyberspace. Therefore, we need a positive attitude and a conscious approach towards digital technology. At this point, the concept of "Digital Citizenship" emerges.

The advancement and proliferation of digital technology turns individuals into digital citizens. According to Vizenor (2014), digital citizenship is an individual's using technology for social, communal, and political aims. According to Farmer (2011), digital citizens are the individuals who participate in digital platforms by selecting and sorting the electronic information appropriately and use the information both for social and personal development. Digital citizenship is "[to] advocate and practice legal, ethical, safe, and responsible use of information and communications technology in the online environments" (ISTE, 2007). Mossberger, Tolbert and McNeal (2007) define digital citizens as individuals who can read, write, understand, and transmit the online information, has broadband access, and use the Internet regularly and effectively. According to Bailey and Ribble 
(2007), "digital citizenship can be described as the norms of appropriate, responsible behavior with regard to technology use."

There are some rules and responsibilities concerning digital citizenship. According to Ribble, Bailey and Ross (2004), these are "the process of teaching and learning about technology and the use of technology, electronic exchange of information, electronic standards of conduct or procedure, electronic precautions to guarantee safety." Digital citizenship is a product of technology-society acculturation rather than a result of constitutional or official rights (Şendağ \& Uysal, 2010).

A lack of knowledge and skills in digital content evaluation is one of the struggles for teachers when it comes to integrating digital technologies into their classes (C. Kim, Kim, Lee, Spector, \& DeMeester, 2013). "Despite the increasing accessibility and availability of technology in classrooms (e.g. open educational resources, e-text books, supplementary digital materials, and software), teachers confront new challenges when using digital technology effectively (Davies and West, 2014). Therefore, "teachers must select appropriate digital resources for their lessons and determine which resources will work best in their classrooms" (M. K. Kim, Xie, and Cheng, 2017). Also teachers must improve their strategies of determining and evaluating digital content (Wiley, Bliss, \& McEwen, 2014).

Attitude towards digital technology and digital citizenship are interrelated. Today's teachers need to adopt a positive attitude towards digital technology, be a good digital citizen, and provide digital learning opportunities to their students. The nature of the relationship between attitudes towards digital technology and digital citizenship on the part of pre-service primary school teachers must be investigated. This study was designed for this purpose. The aim of this study is to investigate the relationship between pre-service primary school teachers' attitudes towards digital technology and their digital citizenship levels in terms of some variables. Therefore, this study seeks answers to the following questions:

1) Is there a significant difference between pre-service primary school teachers' Attitude Scale for Digital Technology (ASDT) scores and Digital Citizenship Scale (DCS) scores in terms of gender, class, having Internet connection, the number of years the participants spend using the Internet, and Internet-using skills?

2) What is the relationship between pre-service primary school teachers' Attitude Scale for Digital Technology levels and Digital Citizenship Scale levels?

3) Do pre-service primary school teachers' Attitude Scale for Digital Technology scores predict their Digital Citizenship Scale levels?

\section{Method}

This study, which investigates the relationship between pre-service primary school teachers' Attitude Scale for Digital Technology levels and Digital Citizenship Scale levels, is designed in associational research model - a sub-category of survey models. This type of research usually analyses associations and connections (Büyüköztürk, Çakmak, Akgün, Karadeniz, \& Demirel, 2008). The sample of the study was selected via convenience sampling method. Convenience sampling can be defined as acquiring data from a group that is convenient to find for the researcher (Büyüköztürk et. al., 2008). The sample of the study is composed of 461 pre-service primary school teachers studying at Adnan Menderes University, Kırıkkale University, Muğla Sitkı Koçman University, and Nevşehir Hacı Bektaş Veli University. The information on the participants is presented in Table 1 below: 
Table 1. The information on the participants

\begin{tabular}{lcc}
\hline Variables & Male & 142 \\
Gender & Female & 319 \\
& Class 2 & 119 \\
Class & Class 3 & 220 \\
& Class 4 & 122 \\
Internet connection & Yes & 34 \\
& No & 454 \\
& Less than 1 year & 6 \\
Years of Internet use & $1-2$ years & 18 \\
& 2-5 years & 98 \\
& More than 5 years & 339 \\
& Less than 1 hour & 18 \\
Daily Internet use & 1-2 hours & 115 \\
& 2-5 hours & 195 \\
& More than 5 hours & 133 \\
Internet using skills & Low & 15 \\
& Intermediate & 285 \\
& Advanced & 155 \\
\hline
\end{tabular}

The data collection tool was Attitude Scale for Digital Technology (ASDT) developed by Cab1 (2016) and Digital Citizenship Scale (DCS) developed by İsman and Güngoren (2014). Attitude Scale for Digital Technology has 39 items and 8 factors. Digital Citizenship Scale, which aims at measuring digital citizenship levels, has 34 items. The results of the reliability tests conducted by the developers of the abovementioned scales reveal that Cronbach Alpha value is .90 for Attitude Scale and .85 for Digital Citizenship Scale. The reliability test results conducted during this study is .87 Cronbach Alpha value for Attitude Scale and .85 for Digital Citizenship Scale. The data was analyzed via SPSS 20.0 program. The data was analyzed by means of descriptive statistics, t-test, one-way analysis of variance for unrelated samples, as well as correlation and regression analysis for the relationship among variables.

\section{Results}

Is there a significant difference between pre-service primary school teachers' Attitude Scale for Digital Technology (ASDT) scores and Digital Citizenship Scale (DCS) scores in terms of gender, class, having Internet connection, the number of years the participants spend using the Internet, and their perceived Internet-using skills?

3.1 Is There a Significant Difference between Pre-Service Primary School Teachers' ASDT Scores and DCS Scores in Terms of Gender?

There is a statistically insignificant difference among pre-service primary school teachers' ASDT scores in terms of gender $\left[\mathrm{t}_{(461)}=.68 . \mathrm{p}>.05\right]$. Similarly, there is a statistically insignificant difference among pre-service teachers' DCS scores in terms of gender $\left[\mathrm{t}_{(461)}=1.49 . \mathrm{p}>.05\right]$. The means of the scores from both scales are close for both genders.

Table 2. t-test results concerning pre-service primary school teachers' gender

\begin{tabular}{lccccc}
\hline & Gender & $\mathbf{N}$ & Means & $\mathbf{t}$ & $\mathbf{p}$ \\
\hline \multirow{2}{*}{ Digital attitude } & Male & 142 & 137.34 & \multirow{2}{*}{0.68} & \multirow{2}{*}{0.496} \\
& Female & 319 & 136.14 & & \\
\multirow{2}{*}{ Digital citizenship } & Male & 142 & 120.10 & \multirow{2}{*}{0.49} & 0.136 \\
& Female & 319 & 117.75 & & \\
\hline
\end{tabular}

3.2 Is There a Significant Difference between Pre-Service Primary School Teachers' ASDT Scores and DCS Scores in Terms of Class?

There is a statistically significant difference among pre-service primary school teachers' ASDT scores in terms 
class $\left[\mathrm{F}_{(2-458)}=4.08 \mathrm{p}<.05\right]$. When paired comparison results are examined, the difference emerges between class 2 and class 4. DCS scores also reveal significant difference. $\left[\mathrm{F}_{(2-458)}=4.637 \mathrm{p}<.05\right]$. The results of the post-hoc tests, conducted to determine which classes create this difference, show that the difference is between class 2 and class 4.

Table 3. ANOVA results concerning pre-service primary school teachers' ASDT and DCS scores

\begin{tabular}{lccccc}
\hline & Sinıf & N & Means & F & p \\
\hline \multirow{4}{*}{ Digital attitude } & Class 2 & 119 & 132.76 & & \\
& Class 3 & 220 & 137.22 & 4.08 & 0.02 \\
& Class 4 & 122 & 138.86 & & \\
& Class 2 & 119 & 115.02 & & \\
Digital citizenship & Class 3 & 220 & 118.95 & 4.637 & 0.01 \\
& Class 4 & 122 & 120.95 & & \\
\hline
\end{tabular}

3.3 Is There a Significant Difference between Pre-Service Primary School Teachers' ASDT Scores and DCS Scores in Terms of Having Internet Connection?

There is an insignificant difference among pre-service primary school teachers' ASDT scores in terms of having Internet connection $\left[\mathrm{t}_{(461)}=1.54 \mathrm{p}>.05\right]$. However, there is a significant difference among DCS scores [ $\mathrm{t}_{(461)}$ $=2.09$. $\mathrm{p}<.05]$. It is seen that the difference is in favor of the ones who have Internet connection

Table 4. t-test results concerning pre-service primary school teachers' ASDT and DCS scores according to having Internet connection

\begin{tabular}{lccccc}
\hline & $\begin{array}{c}\text { Internet } \\
\text { Connection }\end{array}$ & N & Means & t & p \\
\hline Digital attitude & No & 25 & 131.28 & 1.54 & 0.12 \\
& Yes & 454 & 136.81 & & \\
Digital & No & 25 & 112.16 & 2.09 & 0.03 \\
citizenship & Yes & 454 & 118.83 & & \\
\hline
\end{tabular}

3.4 Is There a Significant Difference between Pre-Service Primary School Teachers' ASDT Scores and DCS Scores in Terms of the Number of Years the Participants Spend Using the Internet?

There is a statistically significant difference among pre-service teachers' ASDT scores in terms of the number of years they spend using the Internet $\left[\mathrm{F}_{(3-457)}=5.236 \mathrm{p}<.05\right]$. The results of the post-hoc tests, conducted to determine which units create this difference, show that the difference is between the ones who have been using the Internet for more than 5 years and for 2-5 years.

Table 5. ANOVA results concerning pre-service teachers' ASDT and DCS scores in terms of the number of years they spend using the Internet

\begin{tabular}{lccccc}
\hline & Year & $\mathbf{N}$ & Means & $\mathbf{F}$ & $\mathbf{p}$ \\
\hline \multirow{4}{*}{ Digital attitude } & Less than 1 year & 6 & 133.83 & & \\
& 1-2 years & 18 & 129.38 & & \\
& 2-5 years & 98 & 131.46 & & 0.00 \\
& More than 5 years & 339 & 138.39 & & \\
& Less than 1 year & 6 & 121.33 & & \\
Digital citizenship & 1-2 years & 18 & 110.56 & 4.099 & 0.01 \\
& 2-5 years & 98 & 115.07 & & \\
& More than 5 years & 339 & 119.83 & & \\
\hline
\end{tabular}

3.5 Is There a Significant Difference between Pre-Service Primary School Teachers' ASDT Scores and DCS Scores in Terms of the Duration of Daily Internet Use?

There is a statistically significant difference among pre-service teachers' ASDT scores in terms of the duration of 
daily Internet use $\left[\mathrm{F}_{(3-457)}=4.44 \mathrm{p}<.05\right]$. The results of the post-hoc tests, conducted to determine which units create this difference, show that the difference is between the ones who use the Internet for more than 5 hours and for 2-5 hours. There is an insignificant difference among DCS scores $\left[\mathrm{F}_{(3-457)}=2.48 \mathrm{p}>.05\right]$.

Table 6. ANOVA results concerning pre-service teachers' ASDT and DCS scores in terms of the duration of daily Internet use

\begin{tabular}{lccccc}
\hline & Duration & $\mathrm{N}$ & Means & $\mathrm{F}$ & $\mathrm{p}$ \\
\hline \multirow{4}{*}{ Digital attitude } & Less than 1 hour & 18 & 132.67 & & \\
& $1-2$ hours & 115 & 134.29 & & \\
& $2-5$ hours & 195 & 135.08 & 4.44 & 0.00 \\
& More than 5 hours & 133 & 141.05 & & \\
& Less than 1 hour & 18 & 115.00 & & \\
Digital citizenship & $1-2$ hours & 115 & 116.01 & \multirow{2}{*}{2.48} & 0.06 \\
& 2-5 hours & 195 & 118.49 & & \\
& More than 5 hours & 133 & 121.05 & & \\
\hline
\end{tabular}

3.6 Is There a Significant Difference between Pre-Service Primary School Teachers' ASDT Scores and DCS Scores in Terms of Their Perceived Internet-Using Skills?

There is a statistically significant difference among pre-service teachers' ASDT scores in terms of their Internet-using skills $\left[\mathrm{F}_{(3-457)}=27.6 \mathrm{p}<.05\right]$. This difference is between low and intermediate levels and between intermediate and advanced levels. There is a statistically significant difference among pre-service teachers' DCS scores $\left[\mathrm{F}_{(3-457)}=32.5 \mathrm{p}<.05\right]$. This difference is between low and intermediate levels and between intermediate and advanced levels.

Table 7. ANOVA results concerning pre-service teachers' ASDT and DCS scores in terms of their perceived Internet-using skills

\begin{tabular}{lccccc}
\hline & Level & N & Means & F & p \\
\hline \multirow{4}{*}{ Digital attitude } & Low & 15 & 126.93 & & \\
& Intermediate & 285 & 132.82 & 27.6 & 0.00 \\
& Advanced & 155 & 144.43 & & \\
Digital citizenship & Low & 15 & 105.07 & & \\
& Intermediate & 285 & 115.41 & 32.5 & 0.00 \\
& Advanced & 155 & 125.88 & & \\
\hline
\end{tabular}

3.7 What Is the Relationship between Pre-Service Primary School Teachers' Attitude Scale for Digital Technology Levels and Digital Citizenship Scale Levels?

As it is seen above, the relationship between ASDT and DCS scores is positive and significant $(\mathrm{r}=.759, \mathrm{p}<.05)$, i.e. as ASDT scores of the participants increase, so do their DCS scores. The correlation coefficient indicates that the relationship is strong.

Table 8. Correlation coefficients and descriptive statistics concerning the relationship between ASDT and DCS scores

$* * \mathrm{p}<.01, \mathrm{n}=461$.

\begin{tabular}{lcccc}
\hline Variables & Means & Standard deviation & $\mathrm{t}$ & $\mathrm{p}$ \\
\hline 1- digital attitude & 136.51 & 17.45 & 1 & \\
2- digital citizenship & 118.47 & 15.60 & $0.759^{* *}$ & 1 \\
\hline
\end{tabular}

3.8 Do Pre-Service Primary School Teachers'Attitude Scale for Digital Technology Scores Predict Their Digital Citizenship Scale Levels?

Table 9 shows the results of linear regression analysis which aims at clarifying how much of the variability of 
digital citizenship can be explained by pre-service primary school teachers' digital attitude levels. The analysis results, which are summarized below, are based on the data gathered from 461 students:

Table 9. Regression analysis results concerning digital attitude and digital citizenship variables

\begin{tabular}{lccccc}
\hline Variables & $\mathrm{B}$ & Standart Error B & Beta & $\mathrm{t}$ & $\mathrm{p}$ \\
\hline Invariant & 25.84 & 3.74 & & 6.9 & .00 \\
\hline Digital citizenship & 0.679 & 0.03 & 0.76 & 25.0 & .00 \\
\hline $\mathrm{R}=.759, \mathrm{R}^{2}=.577$ & & & & & \\
$\mathrm{~F}(1.460)=625.42 \mathrm{p}=.000$ & & & & \\
\hline
\end{tabular}

According to the Table 9 shows that ASDT and DCS has a strong relationship - as it has just been revealed in the second sub-question $(\mathrm{r}=.759)$. When we examine the extent to which digital attitude affects the variability of digital citizenship, i.e. how much of the digital citizenship can be explained through digital attitude, regression coefficient shows us that digital attitude is a significant predictor of digital citizenship $\left(r^{2}=.58 . p<001\right)$.

\section{Conclusion \& Discussion}

Negative behaviors such as downloading music from the Internet illegally, plagiarizing via the Internet and using mobile phones during lessons (Yang \& Chen, 2010) make the advancement of digital attitude and digital citizenship skills necessary. These problems can be attributed to lack of Internet literacy (Livingstone, Bober, \& Helsper, 2005). With the significance of this issue in mind, this study has analyzed the ASDT and DCS scores of pre-service primary school teachers who will raise the digital citizens of the future.

According to the results, there is an insignificant difference between ASDT and DCS scores in terms of gender. Studies by Isman and Gungoren (2014) and by Bardakci, Akyuz, Samsa-Yetik, and Keser (2014) conclude that gender is not a significant variable. However, a study by Oyedemi (2012) claims otherwise. Aşıcı and Usluel (2013) and Ono and Zavodny (2007) conclude that gender does not affect access to ICT. Cepni, Oguz, and Kilcan (2014) conclude that male students have higher digital attitude levels than female students.

When the issue of having Internet connection is considered, it has been observed that there is an insignificant difference among digital attitude scores whereas there is a significant difference among digital citizenship scores. DCS scores are higher among the ones who have Internet connection compared to those of who do not possess Internet connection.

There is a significant difference among both ASDT and DCS scores of pre-service primary school teachers in terms of their class. Paired comparison results show that the difference emerges between class 2 and class 4 . The results are in favor of class 4 students. This suggests that the classes pre-service teachers take throughout their higher education and the progress they make affect their interaction with technology. The same educational progress also makes pre-service teachers better digital citizens. Further studies can focus on this finding. The impact of higher education can be studied for a better investigation.

There is a significant difference among both ASDT and DCS scores of pre-service primary school teachers in terms of the duration of their Internet experience. The results show that as the number of years pre-service teachers spend using the Internet increase, so do their ASDT and DCS scores. An increase in length of the duration Internet experience improves the digital citizenship qualities of individuals. This is also true for digital attitude.

Attitude towards technology can be defined as personal choice. However, digital citizenship is not a personal skill that can be developed individually. Although new technologies create better opportunities and advantages that can be used to improve education and teaching, the incidents of abuse and misuse of technology in and out of schools increase (Kaya \& Kaya, 2013). Therefore, it is vital for all individuals to have better digital citizenship perception. Pre-service primary school teachers who will raise the digital citizens of the future must have improved digital citizenship qualities.

There is an insignificant difference among DCS scores of pre-service primary school teachers in terms of the duration of daily Internet use. On the contrary, there is a significant difference among ASDT scores. The participants who use the Internet more on a daily basis have higher ASDT scores. These results suggest that the attitude towards technology is likely to change with the advancement of technology and the Internet.

According to Mossberger et al. (2007), digital citizenship is a skill of online social participation. It is believed that positive use of the Internet can create better outcomes. Accordingly, governments transfer their services into 
electronic platforms (Baqir \& Iyer, 2010) so that individuals can act efficiently as digital citizens.

There is a significant difference among ASDT scores of pre-service teachers in terms of their perceived Internet-using skills. This difference is between low and intermediate levels and between intermediate and advanced levels. This result suggests that when pre-service primary school teachers believe they have advanced skills, they adopt a positive attitude towards digital technologies. The high levels of perceived Internet-use skills also affect DCS scores. Higher levels of self-esteem about the Internet and digital technologies create positive impacts on digital citizenship skills. In other words, participants with digital citizenship qualities perceive their skills as advanced. Shelley et al. (2004) detects a positive relationship between improved computer skills and digital citizenship. Çoklar (2008) states that pre-service teachers are more competent in tasks which require Internet-use skills.

This study concludes that the relationship between ASDT and DCS levels is positive, significant, and strong. It can be deduced that as the ASDT scores of the participants increase, so do their DCS scores. Linear regression analysis results shows us that attitude towards digital technology is a significant predictor of digital citizenship.

\section{References}

Aşıc1, T. B., \& Usluel, Y. K. (2013). Sayısal Uçurumun Üniversite Öğrencilerinin Demografik Özelliklerine Göre Incelenmesi. Hacettepe Üniversitesi Eğitim Fakültesi Dergisi, 44(44).

Bailey, G., \& Ribble, M. (2007). Digital Citizenship in Schools. Eugene or: International Society for Technology in Education.

Baqir, M. N., \& Iyer, L. (2010). e-Government Maturity Over 10 Years: A Comparative Analysis Of E-Government Maturity In Select Countries Around The World. Comparative e-government (pp. 3-22). Springer. https://doi.org/10.1007/978-1-4419-6536-3_1

Bardakci, S., Akyüz, H., Samsa-Yetik, S., \& Keser, H. (2014). Öğretmen Adaylarının Dijital Vatandaşlık Eğilimleri Üzerine Sosyokültürel Bir İnceleme. 8th International Computer \& Instructional Technologies Symposium (ICITS). Trakya University: Edirne.

Büyüköztürk, Ş., Çakmak, E. K., Akgün, Ö. E., Karadeniz, Ş., \& Demirel, F. (2008). Bilimsel Araştırma Yöntemleri. Ankara: Pegem Akademi, 177-184.

Cab1, E. (2016). Dijital Teknolojiye Yönelik Tutum Ölçeği. Kastamonu Eğitim Dergisi, 24(3), 1229-1244.

Çepni, O., Oğuz, S., \& Kilcan, B. (2014). Ilköğretim Öğrencilerinin Dijital Vatandaşliğa Yönelik Görüşleri. Turkish Journal of Social Research/Turkiye Sosyal Arastirmalar Dergisi, 18(3).

Çoklar, A. N. (2008). Öğretmen Adaylarinin Eğitim Teknolojisi Standartlari ile Ilgili Özyeterliklerinin Belirlenmesi. Unpublished Doctoral dissertation). Anadolu University, Institute of Education Sciences, Eskişehir, Turkey.

Coşkun, Y. D. D. M. B. (2015). Iletişim Teknolojilerinin Stratejik Kaynak Yönetimi: Ttaş Örneği. Uluslararası İktisadi ve İdari Bilimler Dergisi, 1(1), 31-53.

Davies, R. S., \& West, R. E. (2014). Technology Integration in Schools. Içinde Handbook of Research on Educational Communications and Technology (pp. 841-853). Springer, New York, NY. https://doi.org/10.1007/978-1-4614-3185-5_68

Farmer, L. (2011). Teaching Digital Citizenship. Içinde E-Learn: World Conference on E-Learning in Corporate, Government, Healthcare, and Higher Education (pp. 99-104). Association for the Advancement of Computing in Education (AACE).

Isman, A., \& Canan Gungoren, O. (2014). Digital Citizenship. Turkish Online Journal of Educational Technology - TOJET, 13(1), 73-77.

ISTE (International Society for Technology in Education). (2007). ISTE standards: Students. Retrieved from http://www.iste.org/docs/pdfs/20-14_ISTE_Standards-S_PDF.pdf

Kalelioğlu, F. (2013). Temel Kavramlar. Öğretim Teknolojileri ve Materyal Tasarımı (Ed. Emine Cabı). Ankara: Pegem Akademi Yayıncilık.

Kaya, A., \& Kaya, B. (2013). Öğretmen Adaylarinin Dijital Vatandaşlik Algisi. International Journal of Human Sciences, 11(2), 346-361.

Kim, C., Kim, M. K., Lee, C., Spector, J. M., \& DeMeester, K. (2013). Teacher Beliefs and Technology Integration. Teaching and Teacher Education, 29, 76-85. https://doi.org/10.1016/j.tate.2012.08.005 
Kim, M. K., Xie, K., \& Cheng, S.-L. (2017). Building Teacher Competency For Digital Content Evaluation. Teaching and Teacher Education, 66, 309-324. https://doi.org/10.1016/j.tate.2017.05.006

Livingstone, S., Bober, M., \& Helsper, E. (2005). Internet Literacy Among Children and Young People: Findings from the UK Children Go Online Project.

Mossberger, K., Tolbert, C. J., \& McNeal, R. S. (2007). Digital Citizenship: The Internet, Society, and Participation. MIt Press.

Ono, H., \& Zavodny, M. (2007). Digital Inequality: A Five Country Comparison Using Microdata. Social Science Research, 36(3), 1135-1155. https://doi.org/10.1016/j.ssresearch.2006.09.001

Oyedemi, T. T. D. (2012). The Partially Digital: Internet, Citizenship, Social Inequalities, and Digital Citizenship in South Africa. University of Massachusetts Amherst.

Ribble, M. S., Bailey, G. D., \& Ross, T. W. (2004). Digital Citizenship: Addressing Appropriate Technology Behavior. Learning \& Leading with technology, 32(1), 6.

Şendağ, S., \& Uysal, Ö. (2010). Vatandaşlıkta Dönüşümler. Bilgi ve İletişsim Teknolojileri Işığında Dönüşümler içinde, 257-279.

Shelley, M., Thrane, L., Shulman, S., Lang, E., Beisser, S., Larson, T., \& Mutiti, J. (2004). Digital Citizenship: Parameters of The Digital Divide. Social Science Computer Review, 22(2), 256-269. https://doi.org/10.1177/0894439303262580

Vizenor, K. V. (2014). Binary Lives: Digital Citizenship and Disability Participation in a User Content Created Virtual World (Ph.D.). Ann Arbor, United States. Retrieved from https://search.proquest.com/docview/1511453197/abstract/A8BD700583964DB5PQ/1

Wiley, D., Bliss, T. J., \& McEwen, M. (2014). Open Educational Resources: A Review of the Literature. Handbook of Research on Educational Communications and Technology (pp. 781-789). Springer, New York, NY. https://doi.org/10.1007/978-1-4614-3185-5_63

Yang, H. H., \& Chen, P. (2010). Exploring Teachers' Beliefs about Digital Citizenship and Responsibility. Technological Developments in Networking, Education and Automation (pp. 49-54). Springer, Dordrecht. https://doi.org/10.1007/978-90-481-9151-2_9

\section{Note}

Note 1 . Some of the data in the paper is orally presented at the "Fifth International Instructional Technologies \& Teacher Education Symposium", and held at October 11th-13th 2017 in Selçuk, İzmir, Turkey hosted by Dokuz Eylul University in collaboration with Anadolu University.

\section{Copyrights}

Copyright for this article is retained by the author(s), with first publication rights granted to the journal.

This is an open-access article distributed under the terms and conditions of the Creative Commons Attribution license (http://creativecommons.org/licenses/by/4.0/). 